\title{
PENINGKATAN AKTIVITAS BELAJAR DAN KEMAMPUAN BERPIKIR KRITIS SISWA DALAM PEMBELAJARAN IPA DENGAN PENDEKATAN PROBLEM BASED LEARNING (PBL) DI KELAS V SDN 06 LIMBANANG KECAMATAN SULIKI
}

\author{
Yati $^{1}$, Mudjiran ${ }^{1}$, Yanti Fitria ${ }^{{ }^{*}}$ \\ *Program Studi Magister Pendidikan Dasar, Fakultas IImu Pendidikan, \\ Universitas Negeri Padang, Padang, Indonesia \\ yanti fitria@fip.unp.ac.id
}

\begin{abstract}
The background of this research is the lack of fifth students' learning activities and critical thinking skills of science learning. This study aims to discuss and obtain data about the improvement of students' learning activities and critical thinking skills in science learning with a problem-based learning (PBL) approach in grade 4 in a public elementary school in Suliki District. This type of research is classroom action research consisting of four stages, namely planning, action, observation, and reflection. This research consists of two cycles and the subjects in this study were 21 fifth grade students, consisting of 11 boys and 10 girls in 2016/2017 academic year. Data collection techniques used were observation sheets and tests. The data were analyzed using percentages and data reduction. The results showed that the implementation of problem-based learning ( $P B L$ ) approach increased students' learning activities and critical thinking skills in science learning which was marked by an increase of an average student's critical thinking ability from 69 in cycle I to 81 in cycle II.
\end{abstract}

Keyword: critical thinking skills; learning activities; problem based learning; sciences.

\section{PENDAHULUAN}

Pendidikan dilihat mulai dari suatu proses hingga sampai tujuan pendidikan tersebut yang merupakan kegiatan kehidupan dalam masyarakat untuk mencapai perwujudan manusia seutuhnya yangberlangsung sepanjang hayat (Dianto, 2015). Pendidikan dapat diartikan sebagai suatu bentuk upaya perwujudan kebudayaan manusia yang dinamis dan sarat akan perkembangan (Yanti, 2013).

Pengembangan pengetahuan, keterampilan dan sikap sesuai dengan pendapat Masnur (2011) yang menjelaskan bahwa, kemampuan kognitif dan daya intelektual individu dapat ditumbuh kembangkan dengan baikmelalui pendidikan. 
Pengembangan peserta didik agar menjadi manusia seutuhnya dan tidak akan lepas dari proses pembelajaran yang merupakan inti dari pendidikan itu sendiri (Sanovan, 2019). Hal ini dapat juga dikatakan bahwa melalui pendidikan dapat membawa dampak kepada kematangan sikap, pengetahuan dan keterampilan siswa.

Upaya mengoptimalkan kemampuan siswa di Sekolah Dasar hendaknya guru mampu merancang pembelajaran dengan membekali siswa dalam tiap langkah pembelajaran dalam rangka meningkatkan kemampuan siswa dar segi fisik maupun secara mental.Akttivitas secara mental tidak terlepas dari aktivitas berpikir khususnya berpikir kritis

Aktivitas yang efektif didalam pembelajaran menurut Oemar (2008) menyatakan bahwa pembelajaran yang mempersiapkan kesempatan untuk belajar sendiri atau melakukan aktifitas dengan sendiri". Aktivitas yang dilakukan peserta didik tersebut menuntut guru bertindak sebagai fasilitator yang bertugas memandu pembelajaran yang bisa membuat siswa aktif secara keseluruhan termasuk mampu berpikir kritis.

Kemamapuan berfikir kritis sangat penting untuk dikembangkan di sekolah agar para peserta didik terbiasa menghadapi berbagai permasalahan di lingkungannya (Lely, Putra, \& Syahrilfuddin, 2020) .Siswa dilatih untuk mempunyai kemampuan kritis dan mampu memcermati berbagai persoalan.

Hasil observasi di kelas $\mathrm{V}$ melalaui wawancaradengan guru kelas $\mathrm{V}$ SD Negeri 06 Limbanang Kecamatan Suliki Tahun Pelajaran 2015/2016, terlihat bahwapembelajaran IPA belum mengarah kepada pembekalan siswa untuk aktif dan mampu berpikir kritis. Dalam pembelajaran IPA, peneliti mengamati materi tentang hubungan antara sifat bahan dengan penyusunnya. Siswa hanya disajikan gambar macam-macam benang, senar, tali, kain, kertas dan tanya jawab tentang gambar tersebut. Kemudian guru langsung menjelaskan masing-masing kegunaan dan kekuatan hanya dari pengamatan gambar yang disajikan saja tanpa melalui eksperimen dan analisa sehingga hanya menyajikan materi dengan dominasi ceramah. Sekama proses pembelajaran berlangsung siswa terlihat tidak aktif. Selain itu ditemukan guru jarang sekali mengembangkan cara belajar kelompok 
dan diskusi sehingga banyak ditemukan siswa yang tidak berani menyampaikan pendapatnya di depan kelas, siswa cenderung diam. Siswa tidak mampu melakukan analisis, sintesis serta evaluasi terhadap masalah-masalah yang ditemui dalam kegiatan belajar mengajar.

\section{KAJIAN TEORITIS}

Aktivitas yang efektif didalam pembelajaran merupakan pembelajaran yang mempersiapkan kesempatan untuk belajar sendiri atau melakukan aktifitas (Oemar, 2008). Aktivitas yang dilakukan peserta didik tersebut menuntut guru bertindak sebagai fasilitator yang bertugas memandu pembelajaran yang bisa membuat siswa aktif secara keseluruhan termasuk mampu berpikir kritis.

Kemamapuan berfikir kritis sangat penting untuk dikembangkan di sekolah agar para peserta didik terbiasa menghadapi berbagai permasalahan di lingkungannya.Siswa dilatih untuk mempunyai kemampuan kritis dan mampu memcermati berbagai persoalan.

Kurangnya kemampuan guru dalam memberikan akses kepada siswa untuk aktif dalam kelompok maupun individu,proses berfikir kritis melalui eksperimen dalam pembelajaran IPA belum terlatih dengan baik. Sehingga siswa menyelesaikan masalah pembelajaran secara individual dan jarang menemui halhal baru melalui pengalaman langsungnya.Pembelajaran sains atau IImu Pengetahuan Alam berperan penting dalam meningkatkan mutu pendidikan, tertutama menghasilkan generasi yang berkualitas, yaitu manusia yang mampu berpikir kritis, kreatif, dan logis. The learning process that utilizes the integration of science for the students as prospective elementary school teachers is necessary (Fitria, 2018). Pembelajaran IPA berhubungan dengan cara mencari tahu tentang alam secara sistematis, sehingga bukan hanya penguasaan kumpulan pengetahuan yang berupa hasil saja tetapi juga merupakan suatu proses penemuan (Fitria, 2017). Pembelajaran IPA di Sekolah Dasar (SD) menekankan pada pemberian pengalaman langsung untuk meningkatkan kemampuan siswa. 
Kemampuan berfikir kritis dan aktivitas belajar siswa yang rendah dalam pembelajaran IPA akan berdampak terhadap prestasi belajar siswa.Guru masih menerapkan pembelajaran yang teacher sehingga pemahaman siswa terhadap materi pembelajaran menjadi kurang dan sifat kritis siswa juga minim. Guru hanya memberikan materi pembelajaran dengan konsep-konsep yang bersifat hafalan saja, kemudian dalam evaluasi guru hanya fokus pada soal-soal tes yang sifatnya level hafalan (pengetahuan). Guru kurang optimal dalammenggunakan modelmodel pembelajaran yang mampu mengaktifkan kemampuan berpikir kritis siswa yang menyebabkan siswa kurang memberikan respondalam proses belajar.

Djamarah (2008) menjelaskan bahwa aktivitas artinya kegiatan atau keaktifan. Jadi segala sesuatu yang dilakukan atau kegiatan yang terjadi baik fisik maupun non fisik, merupakan suatu aktivitas. Aktivitas siswa selama proses pembelajaran merupakan indikator penting dari adanya keinginan siswa untuk belajar. Sehingga hasil belajar siswa pun akan meningkat sesuai harapan.

Begitu juga dengan kemampuan berfikir kritis yang merupakan kemampuan sangat penting. Hal ini seperti yang diungkapkan oleh Susanto (2013) "Kemampuan berfikir kritis merupakan kemampuan atau cara berfikir tentang ide atau gagasan yang berhubungan dengan konsep yang diberikaan. Berpikir kritis juga dapat dipahami sebagai suatu kegiatan menganalisa ide atau gagasan ke arah yang lebih spesifik, membedakan secara tajam, mamilih, mengidentifikasi, mengkaji, dan mengembangkan ke arah yang lebih sempurna. Berpikir kritis berkaitan dengan asumsi bahwa berpikir merupakan potensi yang perlu dikembangkan untuk kemampuan yang optimal". Jadi dapat dikatakan bahwa berpikir kritis merupakan kemampuan yang sangat penting bagi kehidupan sehingga dijadikan tujuan pokok pendidikan.

Mengingat aktivitas belajar dan kemampuan berpikir kritis merupakan suatu masalah yang sangat penting, makauntuk memperbaiki hal tersebutdipilihlahsuatu pendekatan pembelajaran yang diharapkan dapat meningkatkan aktivitas belajar dan kemampuan berpikir kritis siswa dalam memahami materi pembelajaran IPA. Salah satunya caranya yaitu dengan menerapkan pendekatan Problem Based Learning (PBL). Dalam Problem Based Learing (PBL) ini, siswa dituntut untuk 
menghadapi suatu masalah yang nyata dalam kehidupan sehari-hari. Pendekatan pembelajaran Problem Based Learning (PBL) mampu mengembangkan aktivitas dan kemampuan berpikir kritis untuk memecahkan masalah dan dapat mengembangkan kemampuan intelektual siswa (Maisya dkk, 2020).

\section{METODE PENELITIAN}

Penelitian ini merupakan penelitian tindakan kelas yang terdiri dari empata tahapan yaitu perencanaan, pelaksanaan, observsi, dan refleksi.Penelitian ini terdiri dari dua siklus dan subjek dalam penelitian ini adalah siswa kelas V SDN 06 Limbanang Kecamatan Suliki tahun pelajaran 2016/2017. Jumlah siswa 21 orang, yang terdiri dari 11 orang laki-laki dan 10 orang perempuan. Teknik pengumpulan data menggunakan lembar observasi dan tes. Data dianalisis menggunakan persentase dan reduksi data.

\section{HASIL PENELITIAN}

\section{Siklus I}

Tindakan itu berupa rencana pelaksanaan pembelajaran IPA menggunakan pendekatan Problem Based Learning (PBL). Kegiatan ini dimulai dengan merumuskan rancangan tindakan pembelajaran yaitu: 1) Menyusun rancangan tindakan pembelajaran berupa rencana pelaksanaan pembelajaran meliputi: Standar Kompetensi, Kompetensi Dasar, Indikator Pembelajaran, Tujuan Pembelajaran, Materi Pembelajaran, Kegiatan Pembelajaran, Media dan Sumber Pembelajaran, dan Penilaian, 2) Menyusun deskriptor dan kriteria penilaian melalui pendekatan Problem Based Learning (PBL) , 3) Menyusun alat pengumpulan data penelitian berupa: lembar observasi, dan lembar tes, 4) Menetapkan observer untuk mengamati aktivitas guru dan aktivitas siswa, dan membuat catatan lapangan yang dilakukan observer, 5) Membuat LKS siswa dalam pembelajaran, 6) Membuat soal tes kemampuan berpikir kritis siswa, 7) Merancang pembagian kelompok diskusi siswa berdasarkan kemampuan akademik yang heterogen dan perbedaan jenis kelamin. Proses pembelajaran pada siklus 1 dilaksanakan menggunakan pendekatan problem based learning. 
Berdasarkan hasil pengamatan kemampuan berfikir kritis siswa dalam pembelajaran IPA dapat dilihat pada gambar 1.

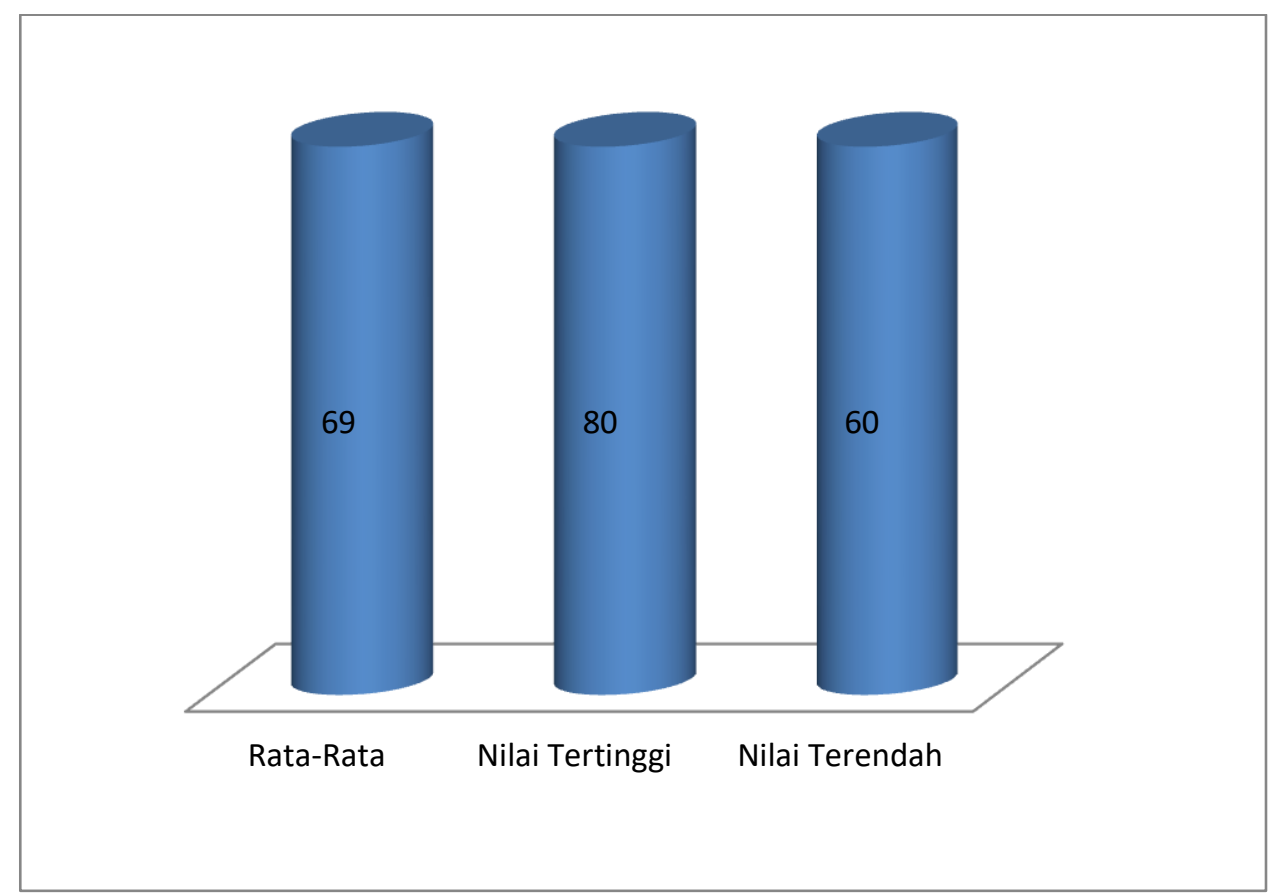

Gambar 1. Kemampuan Berfikir Siswa Siklus I

Berdasarkan gambar 1 dapat dilihat bahwa kemampuan berfikir kritis soiswa yang didapat melalui tes asih berada pada kategori kurang dan cukup.Rata-rata yang didapat sebesar 69 dengan nilai tertinggi 80 dan terendah 60.Dari gambar tersebut dapat disimpulkan bahwa pada siklus 1 kemampuan berfikir kritis siswa masih rendah. Selain itu aktivita sbelajar siswa juga dilakukan pengamatan yang dapat dilihat pada gambar 2 . 


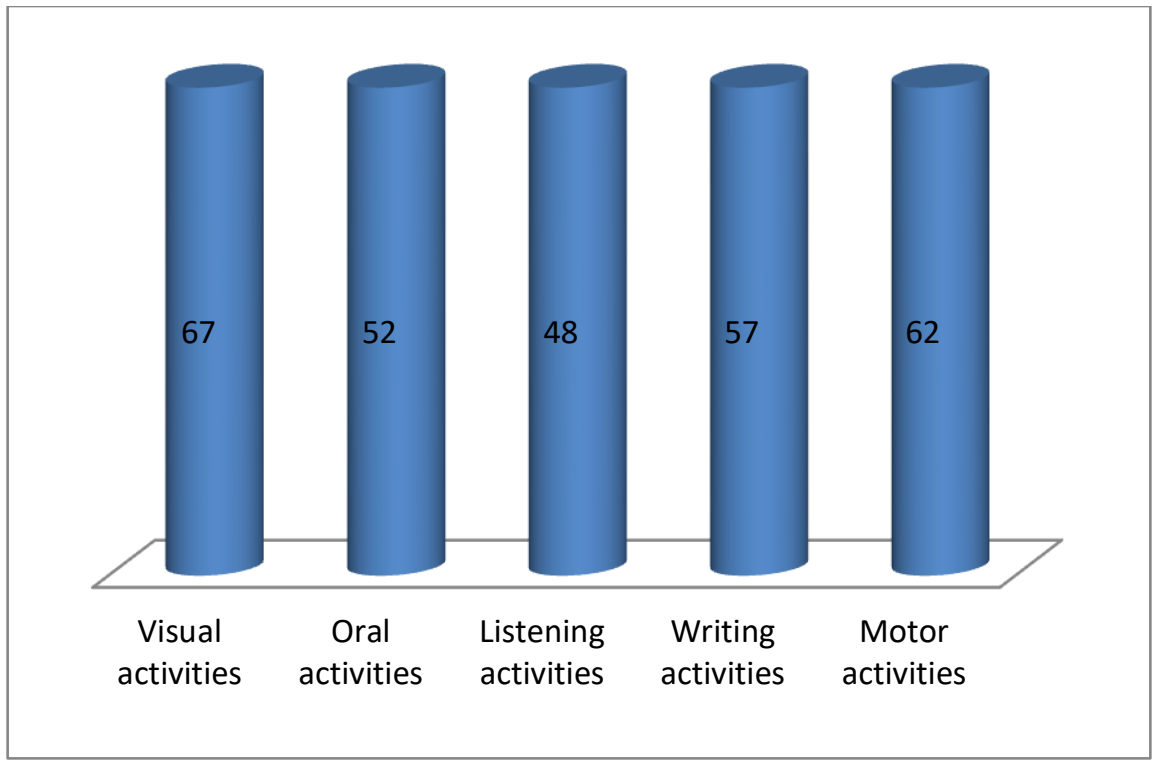

Gambar 2. Aktivitas Belajar Siswa Siklus I

Dari gambar di atas dapat disimpulkan bahwa aktivita sbelajar siswa masih rendah.Hal ini dapat dilihat dari perolehan masing0masing indikator penilain terhadap aktivita belajar siswa. Berdasarkan hasil analisis di atas pembelajaran pada siklus I dengan menerapkan model PBL ini belum mendapatkan hasil yang maksimal yaitu masih banyak kekurangan yang harus diperbaiki ketika proses pembelajaran 1berlangsung seperti yang telah dijelaskan pada hasil observasi terhadap kemampuan berfikir kritis siswa dan aktivitas siswa.

\section{Siklus II}

Pelaksanaan tindakan dilakukan sesuai dengan jadwal yang telah ditentukan oleh pihak sekolah.Pelaksanaan pada siklus II yang dilakukan oleh peneliti adalah memperbaiki tindakan yang dilakukan siklus I dan mempersiapkan alat penunjang lain yang perlu dilakukan pada siklus II. Hal - hal yang dilakukan pada kegiatan Siklus II adalah Perencanaan antara lain :Rencana Pelaksanaan Pembelajaran (RPP) siklus II, lembar observasi atau pengamatan aktivitas siswa dalam proses pembelajaran, lembar observasi atau pengamatan aktivitas guru saat mengajar dengan menerapkan model pembelajaran Problem Based Learning. Berdasarkan 
hasil pengamatan terhadap kemampuan berfikir kritis siswa pada siklus II dapat dilihat pada gambar 3 .

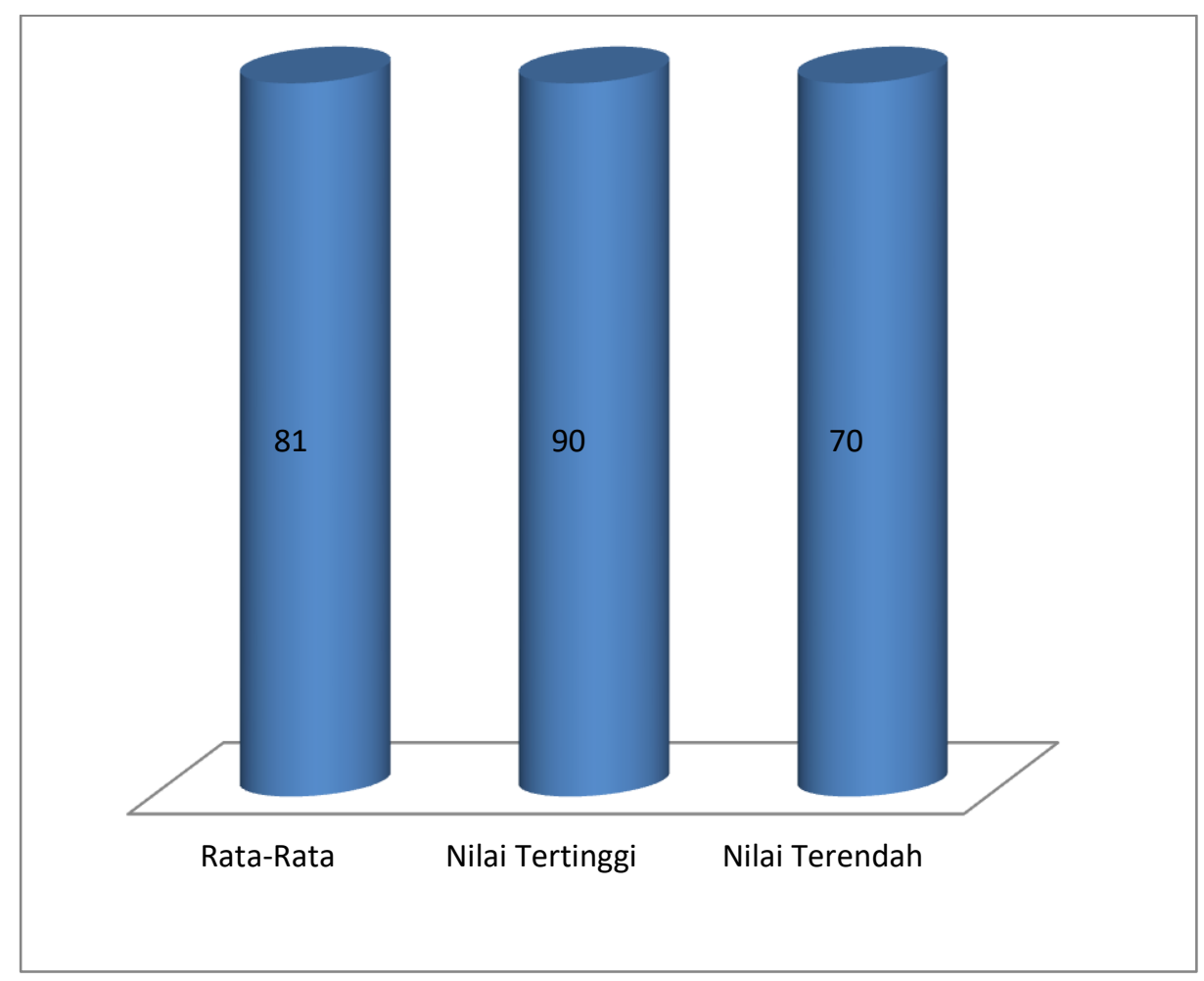

Gambar 3. Kemampuan Berfikir Kritis Siswa Siklus II

Berdasarkan gambar 3 dapat disimpulkan bahwa kemampuan berfikir kritis siswa pada siklus II sudah meningkat dan berada di atas kriteria ketuntasan yang ditetapkan, rata-rata yang didapatkan sebesar 81 dengan nilai tertinggi 90 dan nilai terendah 70. Selain itu aktivitas belajar siswa pada siklus II juga mengalami peningkatan yang dapat dilihat pada gambar 4 . 


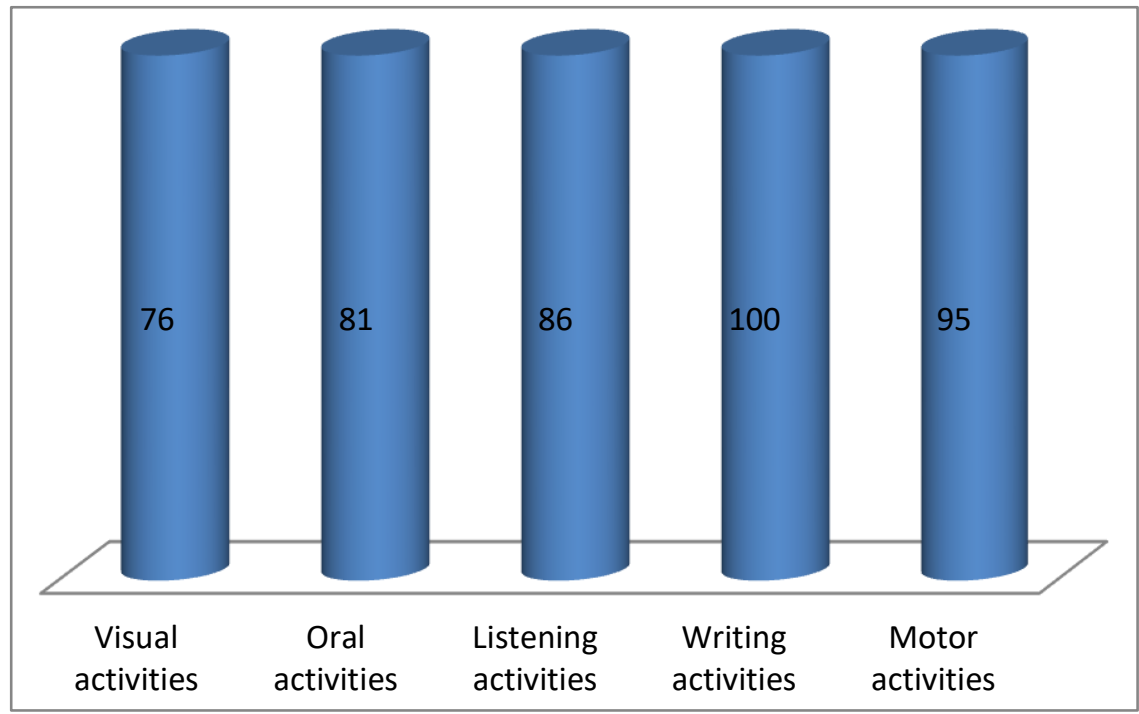

Gambar 4. Aktivitas Belajar Siswa Siklus II

Berdasarkan gambar di atas dapat dilihat bahwa rata-rata aktivitas belajar siswa sudah mencapai target yang ditetapkan. Berdasarkan hasil penelitian, kegiatan pembelajaran yang telah dilakukan oleh guru selama dua siklus dengan menerapkan model pembelajaran Problem Based Learning (PBL) pada kelas $\mathrm{V}$ terjadi peningkatan pada siklus II.

\section{PEMBAHASAN}

Penyelenggaraan pendidikan di Indonesia diharapkan membentuk proses pembelajaran yang berkualitas (Tuasikal, 2016). Disamping itu, diperlukan partisipasi yang tinggi dari semua penyelenggara pendidikan sehingga mampumenghasilkan para peserta didik yang memiliki berbagai kompetensi.Hakekat sains (Ilmu pengetahuanalam, IPA) pada dasarnya merupakan caramengetahui alam dan cara berpikir (way to know and way of thinking) (Fitria, 2017). .Peran pendidikan saat ini sangat membutuhkan paradigma baru seorang pendidik untuk selalu mencari cara mengembangkan solusi (penyelesaian) masalah dan umpan balik terhadap masalah yang ditemui (Fitria, 2014). Berkembangnya kemampuan pemecahan masalah seseorang dipengaruhi oleh pengalaman pengetahuan sebelumnya. Proses perolehan 
pengetahuan yang berlangsung terus menerus secara bermakna oleh peserta didik melalui konstruksi sendiri pengetahuan akan memberikan makna terhadap pemahaman mendalam dan dapat mengembangkan berbagai keterampilan peserta didik diantaranya keterampilan berpikir dan keterampilan pemecahan masalah (Jonassen, 2011).

Dengan merefleksi pembelajaran siklus I, dilakukan perbaikan proses pembelajaran. Perbaikan proses pembelajaran yang dilakukan oleh peneliti yaitu dimulai dari kemampuan berfikir kritis siswa dan aktivitas siswa sehingga diperoleh hasil yang diinginkan. Hal ini sejalan dengan yang dikemukakan oleh Hosnan (2014) bahwa tujuan pembelajaran adalah membantu siswa agar memperoleh berbagai pengalaman dan mengubah tingkah laku siswa, baik dari segi kualitas maupun kuantitas. Perubahan tingkah laku yang dimaksud meliputi pengetahuan, keterampilan dan nilai atau norma yang berfungsi sebagai pengendali sikap dan prilaku siswa.

Dengan demikian aktivitas belajar belajar IPA dan kemampuan berfikir kritis siswa meningkat secara signifikan pada siklus II, sebagaimana harapan peneliti telah tercapai, maka penelitian ini tidak dilanjutkan lagi karena telah mencapai hasil yang diharapkan.Hasil belajar IPA yang diperoleh ini di dukung oleh pendapat Amir (2009:21) yang menjelaskan bahwa PBL ini memepersiapkan mahasiswa untuk berpikir kritis dan analitis, dan untuk mencari serta menggunakan sumber pemebalajaran yang sesuai. Hasil penelitian ini juga di dukung oleh temuan Johari (2013: 66-73) hasi penelitian pelaksanaan PBL dalam proses belajar mereka. Kesimpulannya, PBL adalah strategi pengajaran yang perlu diterapkan dalam proses belajar di lembaga tinggi terhadap pengembangan siswa yang brilian dan terampil.

Lebih lanjut Ngalimun (2009:21) menjelaskan PBL adalah suatu model pembelajaran yang melibatkan siswa untuk memecahkan suatu masalah melalui tahap-tahap metode ilmiah sehingga siswa dapat mempelajari pengetahuan yang berhubungan dengan masalah tersebut dan sekaligus memiliki keterampilan untuk memecahkan masalah.Pembelajaran pada dasarnya merupakan proses interaksi 
dan komunikasi antara guru dan siswa, dimana guru sebagai pengajar dan siswa sebagai pembelajar (Fitria, 2017). Dengan demikian, metode PBL dapat menciptakan suasana lingkungan kelas yang kondusif, aktif, kreatif dan menyenangka, serta membentuk kepribadian pada diri siswa.

\section{SIMPULAN}

Berdasarkan hasil penelitian dan pembahasan dapat disimpulkan bahwa kemampuan berfikir kritis siswa dan aktivitas belajar siswa pada mata pelajaran IPA mengalami peningkatan dengan menggunakan pendekatan model pembelajaran problem based learning. Hal ini dapat dilihat dari peningkatan yang terdapat dari masing-masing siklus.

\section{DAFTAR PUSTAKA}

Ahmad, S. (2013). Teori Belajar dan Pembelajaran di Sekolah Dasar. Jakarta: Kencana Prenada Media Group.

Amir, M. T. (2009). Inovasi Pendidikan Melalui Problem based Learning. Jakarta: Prenada Media Group.

Dianto, M, Gistituati, N \& Mudjiran. (2015). Kontribusi Dukungan Sosial dan Konsep Diri Terhadap Motivasi Berprestasi Siswa di SMP Negeri Kecamatan Batang Kapas Pesisir Selatan.

Djamarah, S. B. (2008). Psikologi Belajar. Jakarta: Rineka Cipta.

Fitria, Y. (2014). Refleksi Pemetaan Pemahaman Calon Guru SD Tentang Integrated Sains Learning. Pedagogi: Jurnal IImu Pendidikan, 14(2), 82-87.

Fitria, Y. (2017). Efektivitas capaian kompetensi belajar siswa dalam pembelajaran sains di sekolah dasar. Jurnal inovasi pendidikan dan pembelajaran sekolah dasar, 1(2).

Fitria, Y. (2017b). Effectiveness of Student Learning Competency Achievements in Learning Science in Primary Schools. Journal of Educational Innovation and Elementary School Learning. Jurnal Inovasi Pendidikan dan Pembelajaran Sekolah Dasar, 1(2), 34-42.

Fitria, Y., \& Idriyeni, I. (2017). Development of Problem-Based Teaching Materials for The Fifth Graders of Primary School. Ta'dib, 20(2), 99-106.

Fitria, Y., Hasanah, F. N., \& Gistituati, N. (2018). Critical Thinking Skills of Prospective Elementary School Teachers in Integrated Science-Mathematics Lectures. Journal of Education and Learning (EduLearn), 12(4), 597-603.

Fitria, Y., Permatasari, A., Sudargo, F., \& Sopandi, W. (2013). Elementary Teacher Student Perspective to Natural Science Learning as Accomodate Effort of 
Need Study Capability. International Journal of science and Research (IJSR), 2(3), 482-485.

Hamalik, O. (2008). Kurikulum dan Pembelajaran. Jakarta: Bumi Aksara.

Jonassen, D. H. (2011). Learning to solve problems: A handbook for designing problem-solving learning environments. Routledge.

Lely, M., Putra, Z. H., \& Syahrilfuddin, S. (2020). Fifth Grade Students' Creative Thinking in Solving Open-Ended Mathematical Problems. Journal of Teaching and Learning in Elementary Education, 3(1), 58-68.

Maisya, R., Hermita, N., Noviana, E., \& Alpusari, M. (2020). Implementasi Metode Outdoor Learning terhadap Complex Problem Solving Skills pada Mata Pelajaran IPA Siswa Kelas VA SDN 56 Pekanbaru. Tunjuk Ajar: Jurnal Penelitian IImu Pendidikan, 3(1), 22-32.

Muslich, M. (2011). Pendidikan Karakter Menjawab Tantangan Krisis Multidimensional. Jakarta: Bumi Aksara.

Ngalimun. 2014. Strategi dan Model Pembelajaran. Yogyakarta: Aswaja Pressindo.

Trianto, (2010). Model Pembelajaran Terpadu. Jakarta: Bumi Aksara 